\title{
PENINGKATAN AKTIVITAS DAN HASIL BELAJAR MELALUI MODEL DISCOVERY LEARNING DENGAN PENDEKATAN SAINTIFIK
}

\author{
Fidya Novita ${ }^{1 *}$, Sri Irawati ${ }^{1}$, dan Dewi Jumiarni ${ }^{1}$ \\ ${ }^{1}$ Program Studi Pendidikan Biologi, Fakultas Keguruan dan Ilmu Pendidikan, Universitas Bengkulu \\ email: fidyanovita6@gmail.com
}

\begin{abstract}
Abstrak
Penelitian ini bertujuan untuk mendeskripsikan aktivitas mengajar guru, aktivitas belajar siswa dan meningkatkan hasil belajar menggunakan model discovery learning dengan pendekatan saintifik di Kelas VIII SMPN 4 Kota Bengkulu. Jenis penelitian ini adalah penelitian tindakan kelas dengan metode deskriptif. Penelitian ini terdiri dari dua siklus, masing-masing siklus terdiri dari 4 tahap yaitu: tahap perencanaan, pelaksanaan, pengamatan dan refleksi. Subjek penelitian ini adalah guru peneliti dan seluruh siswa kelas VIII SMPN 4 Kota Bengkulu. Variabel penelitian ini adalah model discovery learning, aktivitas mengajar guru, aktivitas belajar peserta didik dan hasil belajar. Teknik pengumpulan data dalam penelitian ini yaitu observasi dan tes. Hasil analisis data aktivitas guru siklus I diperoleh skor rata-rata yaitu 18 (baik) dan pada siklus II skor aktivitas guru menjadi 21 (baik). Hasil analisis data aktivitas siswa pada siklus I diperoleh skor rata-rata 18 (baik), dan pada siklus II skor aktivitas siswa menjadi 21 (baik). Selanjutnya persentase ketuntasan hasil belajar pada siklus I yaitu 65,71\% yang termasuk kedalam kriteria belum tuntas dan pada siklus II persentase ketuntasan hasil belajar peserta didik mengalami peningkatan menjadi $82,85 \%$ dan termasuk dalam kriteria tuntas. Dari hasil penelitian dapat disimpulkan bahwa model discovery learning dapat meningkatkan hasil belajar peserta didik di Kelas VIII 5 SMPN 4 Kota Bengkulu.
\end{abstract}

Kata kunci: model discovery learning, pendekatan saintifik, aktivitas, dan hasil belajar

\begin{abstract}
This study aims to describe teacher's teaching activity, student's learning activity and improve learning outcomes using discovery learning model with a scientific approach in class VIII5 SMPN 4 Bengkulu City. The type of this research is Classroom Action Research with descriptive method. This research consists of two cycles, each cycle consist of four phases: planning, implementation, observation and reflection. The subject were teacher and all students of class VIII ${ }_{5}$ SMPN 4 Bengkulu City. The variables of this research are discovery learning model, teacher's teaching activity, student's learning activity and improve learning outcomes. Technique of collecting data in this research is observation and test. The results of data analysis of teacher's activity cycle I obtained average score that is 18 (Good), and in cycle II teacher's activity score to 21 (Good). Results of data analysis of student's activity on the first cycle obtained an average score of 18 (Good), and on the second cycle student's activity score to 21 (Good). Furthermore, the percentage of learning outcomes in the first cycle is $65,71 \%$ included in the criteria of not yet complete and in cycle II the percentage of learning outcomes has increased to $82,85 \%$ and included in the complete criteria. The results of research can be concluded that the model discovery learning can improve learning outcomes with scientific approach of class VIII5 SMPN 4 Bengkulu City.
\end{abstract}

Keywords: discovery learning model, scientific approach, activity and learning outcomes 


\section{PENDAHULUAN}

Salah satu masalah yang dihadapi dunia pendidikan Indonesia adalah lemahnya proses pembelajaran. Proses pembelajaran merupakan suatu kegiatan yang dilaksanakan secara terencana dan terorganisir. Agar proses pembelajaran tersebut dapat berjalan dengan baik, unsur sarana dan prasarana serta penggunaan model dan media pembelajaran perlu diperhatikan. Selain itu, peranan peserta didik dapat berpengaruh dalam proses pembelajaran di sekolah karena peserta didik dipandang sebagai pusat terjadinya proses belajar yang diharapkan aktif, mandiri, bertanggung jawab dan berinisiatif untuk mengenal kebutuhan belajarnya, menemukan sumber-sumber informasi untuk menjawab masalah, membangun serta mempresentasikan kemampuannya berdasarkan kebutuhan dan sumber-sumber yang ditemukan (Sanjaya, 2011). Maka dari itu, pemerintah melakukan suatu kebijakan baru dalam dunia pendidikan dengan menerapkan Kurikulum 2013.

Kurikulum 2013 adalah kurikulum

yang menekankan dalam proses pembelajaran terpusat pada peserta didik (student center) sehingga guru hanya sebagai fasilitator yang merancang pembelajaran agar peserta didik mampu menyelesaikan permasalahan yang kontekstual dan nyata. Dengan demikian, proses pembelajaran lebih aktif dan tidak membosankan, sehingga peserta didik dapat mengonstruksi pengetahuan dan keterampilannya melalui fakta-fakta yang ditemukan dalam penyelidikan guna pembelajaran. Salah satu mata pelajaran dalam kurikulum 2013 adalah Ilmu Pengetahuan Alam (IPA) (Hilda, 2015).

IPA merupakan mata pelajaran di SMP/MTS yang bertujuan untuk meningkatkan pengetahuan, konsep dan keterampilan. Pengetahuan IPA diperoleh melalui suatu proses ilmiah yang memberikan kesempatan kepada peserta didik untuk memperoleh pengalaman langsung sehingga dapat menambah kemampuan untuk menerima, menyimpan dan menerapkan konsep yang telah dipelajari. Dengan demikian, peserta didik terlatih untuk menemukan sendiri berbagai konsep yang dipelajari secara menyeluruh, bermakna, autentik dan aktif (Permendikbud, 2014).

Berdasarkan hasil observasi dan wawancara awal yang dilakukan peneliti pada kegiatan Magang 3 di SMP Negeri 4 Kota Bengkulu khususnya kelas $\mathrm{VIII}_{5}$ yang merupakan subjek penelitian dari peneliti, diperoleh informasi sebagai berikut: 1) Pembelajaran yang dilakukan hanya menggunakan metode ceramah, diskusi, tanya jawab sehingga guru kurang melibatkan peserta didik dalam memecahkan masalah untuk dikaitkan dengan materi pembelajaran, 2) Minat belajar peserta didik masih kurang karena tidak adanya variasi model pembelajaran yang dilakukan guru, 3) Guru kurang memotivasi peserta didik sehingga hasil belajar peserta didik relatif rendah. Hal ini dapat dilihat dari hasil ulangan peserta didik materi gerak pada makhluk hidup. Hasil belajar dikatakan rendah apabila tidak mencapai nilai KKM yang ditetapan SMP Negeri 4 yaitu 75.

Pendekatan saintifik merupakan suatu pendekatan dimana proses pembelajarannya dirancang sedemikian rupa agar peserta didik secara aktif mengonstruksi konsep, hukum atau prinsip melalui tahapan-tahapan saintifik seperti: mengamati, menanya, mengumpulkan data, mengasosiasi dan mengkomunikasikan. Pendekatan saintifik dimaksudkan untuk memberikan pemahaman kepada peserta didik dalam mengenal dan memahami berbagai konsep materi melalui pendekatan ilmiah. Pendekatan saintifik menjadikan pembelajaran lebih aktif dan tidak membosankan sehingga peserta didik dapat mengonstruksi pengetahuan dan keterampilannya melalui fakta-fakta yang ditemukan dalam penyelidikan guna pembelajaran. Dalam penerapan pendekatan saintifik diperlukan suatu model pembelajaran. Salah satu model 
pembelajaran yang dapat digunakan untuk menerapkan pendekatan saintifik adalah model discovery learning (Kemendikbud, 2013).

Menurut Hosnan (2014) model discovery learning pertama kali dikemukakan oleh Jerome Bruner pada tahun 1915. Model discovery learning merupakan suatu model yang menekankan pada pemahaman struktur atau ide-ide penting terhadap suatu disiplin ilmu, melalui keterlibatan peserta didik secara aktif dalam proses pembelajaran. Proses pembelajarannya bertujuan untuk mengembangkan cara belajar peserta didik aktif dengan menemukan sendiri dan menyelidiki sendiri, sehingga akan diperoleh hasil yang tahan lama dalam ingatan serta tidak mudah dilupakan peserta didik. Dengan demikian, peserta didik bisa belajar berpikir analisis dan mencoba memecahkan sendiri masalah yang dihadapi (Hosnan, 2014).

Tujuan penelitian ini adalah untuk meningkatkan aktivitas mengajar guru, aktivitas belajar peserta didik dan hasil belajar di Kelas VIII 5 SMPN 4 Kota Bengkulumealui model discovery learning dengan pendekatan saintifik.

\section{METODE}

Penelitian ini merupakan Penelitian Tindakan Kelas (PTK) dengan metode deskriptif yang dilakukan dalam dua siklus, masing-masing siklus terdiri dari 4 tahap yaitu: tahap perencanaan, pelaksanaan, pengamatan dan refleksi. Penelitian dilaksanakan pada semester genap tahun ajaran 2017/2018 di SMPN 4 Kota Bengkulu. Peran peneliti dalam penelitian ini adalah sebagai guru biologi yang mengajar peserta didik pada materi Sistem Ekskresi. Guru dibantu 2 orang observer yang mengobservasi aktivitas mengajar guru dan aktivitas belajar peserta didik dalam kegiatan pembelajaran menggunakan model discovery learning dengan pendekatan saintifik.

Subjek penelitian yaitu peserta didik kelas VIII 5 SMPN 4 Kota Bengkulu berjumlah
36 orang yang terdiri dari 23 orang perempuan dan 13 orang laki-laki.

Teknik pengumpulan data dalam penelitian ini adalah observasi dan tes. Lembar observasi aktivitas mengajar guru, lembar observasi aktivitas belajar peserta didik dan lembar tes hasil belajar. Lembar tes hasil belajar terdiri dari soal uraian yang digunakan untuk mengukur hasil belajar peserta didik. Soal-soal uraian pada lembar tes dirumuskan berdasarkan 3 aspek kognitif yaitu: C1 (pengetahuan), C2 (pemahaman), dan C3 (penerapan). Data hasil observasi aktivitas mengajar guru dan aktivitas belajar peserta didik dianalisis dengan rumus:

$\mathrm{X}=\frac{\sum X}{N}$ (Sudijono, 2014)

Keterangan:

$X \quad$ : Rata-rata skor

$\sum X \quad$ : Jumlah skor pengamatan DL

$\mathrm{N} \quad$ : Jumlah pengamat

Kategori rerata skor aktivitas peserta didik terdiri dari 3 kategori yaitu baik, cukup dan kurang. Kisaran skor untuk tiap kategori ditentukan dengan rumus:

Kisaran skor $=\frac{\text { skor tertinggi-skor terendah }}{\text { jumlah kategori penilaian }}$

(Arikunto, 2013)

Keterangan:

Skor tertinggi : jumlah butir pengamatan $\mathrm{x}$ skor maksimum setiap butir

Skor terendah: jumlah butir pengamatan $\mathrm{x}$ skor minimum setiap butir

Kategori rerata skor aktivitas mengajar guru dan aktivitas belajar peserta didik dapat dilihat pada Tabel 1.

Tabel 1. Kategori Rerata Skor Aktivitas Mengajar Guru Dan Aktivitas Belajar Peserta Didik Rentang skor Kategori Penilaian

\begin{tabular}{cc}
\hline $7-11$ & Kurang \\
$12-16$ & Cukup \\
$17-21$ & Baik \\
\hline
\end{tabular}


Data hasil belajar peserta didik dianalisis dengan rata-rata skor dan persentase kentuntasan klasikal dengan rumus:

$X=\frac{\sum X}{N}$

(Sudijono, 2014)

Keterangan rumus pada penelitian ini adalah: $X \quad$ : Rata-rata skor

$\sum X \quad$ : Jumlah skor kemampuan hasil belajar

$N \quad$ : Jumlah peserta didik

Kategori rerata skor hasil belajar yang mengacu pada kriteria ketuntasan minimum (KKM) SMPN 4 Kota Bengkulu yaitu 75.

Persentase ketuntasan klasikal ditentukan dengan rumus:

$\mathrm{P}=\frac{\sum X}{N} \mathrm{X} 100 \%$

(Sudijono, 2014)

Keterangan rumus pada penelitian ini adalah: $\sum x \quad$ : Jumlah siswa yang berada di bawah/di atas KKM

$\mathrm{N} \quad$ : Jumlah seluruh siswa

P : Persentase ketuntasan hasil belajar

\section{HASIL DAN PEMBAHASAN}

Berdasarkan hasil penelitian yang telah dilakukan hasil observasi aktivitas mengajar guru dan aktivitas belajar peserta didik dalam kegiatan pembelajaran model discovery learning dengan pendekatan saintifik dapat dilihat pada Tabel 2 dan Tabel 3.

Tabel 2. Rerata Skor dan Kategori Aktivitas Mengajar Guru

\begin{tabular}{ccc}
\hline Siklus & Rerata Skor & Kategori \\
\hline I & 18 & Baik \\
II & 21 & Baik \\
\hline
\end{tabular}

Tabel 3. Rerata Skor dan Kategori Aktivitas Belajar Peserta Didik Guru

\begin{tabular}{ccc}
\hline Siklus & Rerata Skor & Kategori \\
\hline I & 18 & Baik \\
II & 21 & Baik \\
\hline
\end{tabular}

Proses pembelajaran melalui model discovery learning dengan pendekatan saintifik terdiri dari 6 tahap, yaitu: Stimulation (pemberian rangsangan), Problem statement (pernyataan/ identifikasi masalah), Data collecting (pengumpulan data), Data processing (pengolahan data), Verification (Pembuktian) dan kesimpulan.

Hasil penelitian menunjukkan bahwa pada siklus I walaupun aktivitas guru telah menunjukkan kategori baik. Namun masih ada beberapa aspek yang berkategori cukup. Adapun aspek yang berkategori cukup sebagai berikut :

1. Guru mengarahkan kelompok peserta didik untuk mengemukakan pendapatnya tentang pertanyaan yang telah diberikan. Pada kegiatan ini guru hanya mengarahkan 3-4 kelompok dari 6 kelompok untuk mengemukakan pendapatnya mengenai pertanyaan proses terbentuknya urin.

2. Guru membimbing kelompk peserta didik dalam melakukan pembuktian/ verifikasi data. Pada kegiatan ini guru membimbing 3-4 kelompok dalam melakukan pembuktian/ verifikasi mengenai proses penyaringan darah pada ginjal melalui membandingkan hasil percobaan dengan buku IPA pegangan peserta didik.

3. Guru membimbing kelompok peserta didik untuk membuat kesimpulan hasil percobaan. Pada kegiatan ini guru hanya membimbing 3-4 kelompok dari 6 kelompok untuk membuat kesimpulan berdasarkan tujuan dan hasil percobaan model penyaringan darah pada ginjal yang terdapat di LKPD.

Berdasarkan kekurangan-kekurangan tersebut guru melakukan perbaikan aktivitas mengajar guru di siklus II. Upaya guru dalam melakukan perbaikan menyebabkan terjadinya peningkatan rata-rata skor aktivitas mengajar guru di siklus II menjadi 21 yaitu dengan kategori baik. 
Pada aktivitas peserta didik siklus I sudah berkategori baik. Namun masih ada beberapa aspek yang berkategori cukup. Adapun aspek yang berkategori cukup sebagai berikut :

1. Kelompok peserta didik mengemukakan pendapatnya tentang pertanyaan yang telah diberikan. Pada kegiatan ini hanya 3-4 kelompok dari 6 kelompok mengemukakan pendapatnya mengenai pertanyaan proses terbentuknya urin.

2. Kelompok peserta didik melakukan pembuktian/verifikasi data. Pada kegiatan ini hanya 3-4 kelompok dari 6 kelompok dalam melakukan pembuktian/verifikasi mengenai proses penyaringan darah pada ginjal melalui membandingkan hasil percobaan dengan buku IPA pegangan peserta didik

3. Kelompok peserta didik membuat kesimpulan hasil percobaan. Pada kegiatan ini hanya 3-4 kelompok dari 6 kelompok membuat kesimpulan berdasarkan tujuan dan hasil percobaan model penyaringan darah pada ginjal yang terdapat di LKPD.

Berdasarkan kekurangan-kekurangan tersebut guru melakukan perbaikan belajar peserta didik di siklus II. Upaya guru dalam melakukan perbaikan menyebabkan terjadinya peningkatan rata-rata skor aktivitas belajar peserta didik di siklus II menjadi 21 yaitu dengan kategori baik.

Untuk data mengenai hasil belajar peserta didik dapat dilihat pada Tabel 4.

Tabel 4. Hasil Belajar Peserta Didik

\begin{tabular}{cccccc}
\hline Siklus & $\begin{array}{c}\text { Jumlah } \\
\text { seluruh } \\
\text { peserta } \\
\text { didik }\end{array}$ & $\begin{array}{c}\text { Jumlah } \\
\text { peserta didik } \\
\text { yang } \\
\text { memperoleh } \\
\text { nilai } \geq 75\end{array}$ & $\begin{array}{c}\text { Nilai rata- } \\
\text { rata }\end{array}$ & $\begin{array}{c}\text { Persentase } \\
\text { ketuntasan klasikal }\end{array}$ & Kategori \\
\hline I & 35 & 23 & 72,14 & $65,71 \%$ & Belum tuntas \\
II & 35 & 29 & 83,14 & $82,85 \%$ & Tuntas \\
\hline
\end{tabular}

Hasil penelitian menunjukkan bahwa hasil belajar peserta didik mengalami peningkatan dari siklus I ke siklus II. Pada siklus I diketahui bahwa jumlah persentase ketuntasan klasikal peserta didik sebesar $65,71 \%$ ini sudah dikategorikan tinggi tetapi belum mencapai ketuntasan klasikal yang telah ditetapkan yaitu sebesar $75 \%$. Sehingga pada siklus I ini ketuntasan klasikal peserta didik belum dikatakan tuntas. Sedangkan pada siklus II diketahui bahwa ketuntasan belajar klaksikal peserta didik mengalami peningkatan menjadi $82,85 \%$.Nilai ini sudah dikategorikan sangat tinggi dan sudah mencapai ketuntasan belajar klasikal yang telah ditetapkan yaitu sebesar $75 \%$. Sehingga pada siklus II ini ketuntasan klasikal peserta didik dikatakan tuntas. Dari data tersebut terjadi peningkatan hasil belajar kognitif dari siklus I ke siklus II sebesar 17,14 \%.
Peningkatan jumlah persentase belajar klasikal peserta didik dari siklus I ke siklus II menunjukkan bahwa model pembelajaran discovery learning dapat meningkatkan hasil belajar kompetensi pengetahuan. Hal ini sesuai dengan penelitian sebelumnya yang dilakukan oleh Amyani (2017) bahwa model discovery learning dapat meningkatkan aktivitas dan hasil belajar IPA peserta didik. Pada penelitian Widiadnyana, Sadia dan Suastra (2014) menyimpulkan bahwa model discovery learning dapat meningkatkan hasil belajar IPA dan sikap ilmiah peserta didik. Selanjutnya pada penelitian Wulandari, Sunarto, dan Salman (2015) menunjukkan model discovery learning dapat meningkatkan kemampuan berpikir kritis dan hasil belajar. Dimyati dan Mudjiono (2015) yang menyarankan dalam menerapkan langkahlangkah pembelajaran yang akan dilakukan 
oleh guru salah satunya menerapkan model pembelajaran discovery learning. Dimana telah dikemukan oleh Joolingen (1999) dalam Kurniasih (2015) bahwa discovery learning merupakan tipe pembelajaran IPA dimana peserta didik membangun pengetahuannya melalui eksperimen dengan objek, mengambil kesimpulan dari hasil eksperimen.

Pengukuran atau penilaian kompetensi pengetahuan ini menurut Kosasih (2014) bertujuan untuk mengukur kemampuan peserta didik yang bersifat kognitif. Hal ini didukung juga oleh Sani (2014) bahwa pembelajaran discovery learning merupakan metode pembelajaran kognitif yeng menuntut guru lebih kreatif menciptakan situasi yang dapat membuat peserta didik belajar aktif menemukan pengetahuan sendiri. Metode belajar ini sesuai dengan teori Bruner yang menyarankan agar peserta didik belajar secara aktif untuk membangun konsep dan prinsip. Kegiatan discovery melalui kegiatan eksprimen dapat menambah pengetahuan dan keterampilan peserta didik secara simultan. Ini artinya kemampuan peserta didik dalam ranah kognitif sudah meningkat dan telah tuntas untuk mencapai tujuan pembelajaran yang telah ditetapkan.

Pada siklus I materi Sistem Ekskresi, soal yang banyak dijawab benar oleh peserta didik adalah soal nomor 2. Pada soal nomor 1 hanya 10 orang yang dapat menjawab dengan benar hal ini dikarenakan peserta didik belum memahami struktur pada ginjal. Adapun pada soal nomor 2 merupakan soal yang mudah dijawab oleh peserta didik pada siklus I. Pada soal ini sebanyak 26 orang dapat menjawab dengan benar hal ini dikarenakan peserta didik telah memahami proses penyaringan darah diginjal melalui percobaan yang telah dilakukan. Selanjutnya, pada soal nomor 3 hanya 3 orang yang menjawab dengan benar karena peserta didik belum memahami proses terbentuk urine.

Selanjutnya, pada siklus II materi Sistem Ekskresi, soal yang banyak dijawab benar oleh peserta didik adalah soal nomor 1. Pada soal nomor 1 merupakan soal yang mudah dijawab oleh peserta didik pada siklus II. Pada soal ini sebanyak 35 orang dapat menjawab dengan benar hal ini dikarenakan peserta didik telah memahami nama penyakit pada urin yang mengandung gula. Alasan lain yaitu karena soal nomor 1 ini termasuk soal dengan tingkatan kesulitan yang paling rendah yaitu tingakat C1 (pengetahuan). Menurut Uno, dkk (2012) soal tingakat C1 (pengetahuan) diartikan sebagai kemampuan seseorang dalam menghafal atau mengingat kembali pengetahuan yang pernah diterimanya. Sehingga peserta didik dituntut untuk mengingat materi yang telah disampaikan. Adapun pada soal nomor 2 hanya 8 orang yang dapat menjawab dengan benar hal ini dikarena peserta didik belum memahami penyebab terjadinya penyakit albuminaria. Soal nomor 3 hanya 11 orang yang dapat menjawab dengan benar hal ini karena peserta didik belum memahami bagaimana penerapan pola hidup sehat untuk menjaga ginjal.

Peningkatan hasil belajar peserta didik dari siklus I ke siklus II ini menunjukkan bahwa model discovery learning dengan pendekatan saintifik ini dapat diterapkan karena dapat mengikutsertakan seluruh peserta didik terlibat secara aktif dalam membangun konsep pelajaran, peserta didik dapat berpikir untuk menemukan konsep yang belum pernah mereka tahu sebelumnya dan berani menyampaikan hasil temuan mereka dengan menjawab pertanyaan secara tertulis pada lembar kerja peserta didik dan menyampaikannya didepan kelas. Sebagaimana menurut Hosnan (2014) karakteristik discovery learning adalah ciri utama belajar menemukan, yaitu 1) mengeksplorasi dan memecahkan masalah untuk menciptakan, manggabungkan, dan menggeneralisasi pengetahuan; 2) berpusat pada peserta didik; 3) kegiatan untuk menggabungkan pengetahuan baru dan pengetahuan yang sudah ada. 
Selain hal tersebut peserta didik juga dapat mengingat konsep yang baru dipelajari dalam waktu yang lebih lama karena peserta didik secara mandiri menemukan sendiri konsep yang ada. Hal ini dibuktikan dengan pencapaian hasil pelajar peserta didik yang baik dan meningkat di siklus II. Sebagaimana pendapat Kusuma (2015) model pembelajaran discovery merupakan suatu cara untuk mengembangkan belajar peserta didik aktif dengan menemukan sendiri, menyelidiki sendiri, maka hasil yang akan diperoleh akan tahan lama dalam ingatan.

\section{PENUTUP}

\section{Simpulan}

Penerapan model discovery learning dengan pendekatan saintifik dapat meningkatkan aktivitas mengajar guru, aktivitas belajar peserta didik, dan hasil belajar pesera didik kelas VIII5 SMPN 3 Kota Bengkulu pada materi sistem eksresi. Hal ini terlihat dari rata-rata skor aktivitas guru yang diperoleh dari siklus I sebesar 18 (Baik), dan pada siklus II mengalami peningkatan menjadi 21 (Baik). Aktivitas peserta didik yang diperoleh pada siklus I sebesar 18 (Baik), dan pada siklus II mengalami peningkatan menjadi 21 (Baik). Peningkatan aktivitas peserta didik diikuti dengan peningkatan hasil belajar peserta didik. Hal ini terlihat dari rata-rata skor hasil belajar peserta didik pada siklus I yaitu 65,71 $\%$ dan pada siklus II mengalami peningkatan menjadi $82,85 \%$.

\section{Saran}

Berdasarkan hasil penelitian yang telah dilakukan, maka disarankan bagi guru dan peneliti selanjutnya bahwa perlu dilakukan penelitian dengan mengukur hasil belajar dengan enam jenjang kognitif.

\section{Daftar Pustaka}

Amyani. 2017. Penerapan Model Discovery learning (DL) Pada materi Sistem Ekskresi Manusia Untuk Meningkatkan Aktivitas Dan Hasil Belajar Di Kelas VIII2 SMPN 3 Kota Bengkulu. Skripsi tidak diterbitkan. Bengkulu: Program Studi Pendidikan Biologi FKIP Universitas Bengkulu.

Arikunto, S. 2010. Prosedur Penelitian Suatu Pendekatan Praktik. Jakarta: Rineka Cipta.

Dimyati dan Mudjiono. 2015. Belajar dan Pembelajaran. Jakarta: PT Rineka Cipta.

Hilda, L. 2015. Pendekatan Saintifik pada Proses Pembelajaran. Jurnal Darul 'Ilmi, 3(1);76-85. Diakses pada tanggal 18 November 2017 dihttp://perpustakaanstainpsp.net /ejournal/index.php/darulilmi/artic le/view/354/351.

Hosnan. 2014. Pendekatan Saintifik Dan Konstektual Dalam Pembelajaran Abad 21. Bogor: Ghalia Indonesia.

Kemendikbud, 2013. Pengembangan kurikulum 2013. Paparan mendikbud dalam sosialisasi kurikulum. Jakarta: kemendikbud.

Kosasih. 2014. Strategi Belajar dan Pembelajaran. Bandung: Yrama Widya.

Kurniasih, S. 2015. Pengembangan LKS berbasis Model Discovery learning sebagai Upaya Peningkatan Hasil belajar pada Materi Respirasi untuk Kelas VII SMPN 1 Pondok Kelapa. Skripsi tidak diterbitkan. Bengkulu: Program Studi Pendidikan Biologi FKIP Universitas Bengkulu.

Kusuma, T. A., Indawati., Alex. H. 2015. Model Discovery learning Disertai Teknik Probing Prompting Dalam 
Pembelajaran Fisika di MA. Jurnal Pendidikan Fisika, 3:4. Diakses tanggal $15 \quad$ April 2018 dihttp://perpustakaan.net/pendidi kanfisika /article/view/325/31.

Sani, Ridwan Abdullah. 2014. Pembelajaran Saintifik Untuk Implementasi Kurikulum 2013. Jakarta : Bumi Aksara.

Sanjaya. 2011. Strategi Pembelajaran. Jakarta : Prenada.

Sudijono, A. 2014. Pengantar Statistik Pendidikan. Jakarta: Rajawali Pers.

Uno, Hamzah B., Koni., Satria. 2012. Assessment Pembelajaran. Jakarta: Bumi Aksara.

Widiadnyana, Sadia dan Suastra. 2014. Pengaruh Model Discovery learning Terhadap Hasil belajar IPA dan Sikap IImiah Siswa SMP. E-journal Program Pascasarjana Universitas Pendidikan Ganesha, 4 (1); 8-11. Diakses tanggal 15 April 2018. http://pasca.undiksha.ac.id/ejourn al/index.php/jurnal ipa/article/vie $\underline{w / 134}$

Wulandari, Sunarto, dan Salman. 2015. Implementasi Model Discovery learning Dengan Pendekatan Saintifik Untuk Meningkatkan Kemampuan Berfikir Kritis Dan Hasil Belajar Peserta didik Mata Pelajaran Ekonomi Kelas Xi lis I Sma Negeri 6 Surakarta Tahun Pelajaran 2014/2015, 3 (7): (1);1-12. Diakses pada tanggal 18 November $2017 \mathrm{di}$ http.jurnal.fkip.uns.ac.id/index.php /ptn/article/view. 